\title{
Development and validation of a scale to measure exposure to violence in mexican adolescents: exploratory and confirmatory factor analysis
}

\begin{abstract}
The aim of the study was to determine the psychometric properties of the Exposure to Violence Scale (EVS). A derivative sequential mixed method was used. The scale is a self-report questionnaire that evaluates the level of exposure to violence. Item design was based on youth interviews and were reviewed by national and international experts on violence and psychometrics. The scale was answered by a random cluster sample of 1988 middle school students. Exploratory and confirmatory factor analyses were performed and concurrent validity was evaluated. The final version of the scale consists of 7 items in 2 factors that measure violence experienced and witnessed. Both factors have a reliability greater than Cronbach's Alpha of 0.81 . The confirmatory model fulfills all the requirements to be considered reliable and valid. The maximum shared variance between factors was smaller than 0.5 and a common latent factor between the 7 items and 2 factors was found. Based on these results we conclude that Scale of Exposure to Violence has good psychometric properties, being reliable and valid for Mexican adolescents
\end{abstract}

Keywords: exposure to violence, scale, social psychology, adolescents, design and validation, psychometry
Volume 7 Issue 5 - 2018

\author{
Jaime Sebastián F Galán-Jiménez, Omar \\ Sánches-Armáss-Cappello, Luis Felipe \\ García-y-Barragán \\ Faculty of Psychology, Autonomous University of San Luis \\ Potosí, Mexico
}

Correspondence: Jaime Sebastián F Galán-Jiménez, Faculty of Psychology, Autonomous University of San Luis Potosí, Mexico, Email psic.sebastiangalan@gmail.com

Received: September 06, 2018 | Published: October 02, 2018

\section{Introduction}

In Mexico, the Instituto Nacional de Estadística, Geografía e Informática (National Institute of Statistics, Geography and Computing; INEGI, 2014) reported that $30.9 \%$ of the houses had at least one victim of violence. The Global Peace Index $(2013 ; 2015)$ ranked Mexico in the $131^{\text {st }}$ place in 2014 and then in the $144^{\text {th }}$ place in 2015 out of 161 countries. ${ }^{1}$ proposed that living in violent communities is harmful, especially for children and adolescents. Describe that the exposure to violence is not only experienced by the victim when there is a direct exposure but can also be experienced by an observer; an indirect exposure. $^{2}$ The indirect exposure can occur when one is a witness or simply by being informed of the violence experienced by others, which is also supported. ${ }^{3}$ Violence exposure rates from direct victims of violence in different populations range between $20 \%$ and $50 \%$. Furthermore, $30 \%$ to $95 \%$ of people reported being exposed to indirect violence. ${ }^{4-8}$ Adolescents exposed to high levels of violence show emotional numbing (less distress) and anxiety symptoms that worsen with violence exposure. ${ }^{9}$ suggest that witnessed violence could affect perception, behavior, emotions and physique. ${ }^{10}$ found that community violence has a "decidedly larger and more significant effect" (p. 329) on the aggression reported two years later. ${ }^{11}$ propose that witnessed or experienced violence "increases the risk of running away from home, leaving school, pregnancy, suicidal attempts, and having contact with the criminal justice system during adolescence" (p. 2). ${ }^{12}$ Exposure to violence is related to violent behavior, depression, anxiety, posttraumatic stress, self-esteem, aggression, transgression, and constant exposure could make violence seem as acceptable, expected or normal. All of these consequences may be related to the proximity or closeness to the aggressor, duration of the exposure, social norms, and values. ${ }^{12-16}$ There are some instruments measuring some aspects of violence. Proposed the Conflict in Adolescent
Dating Relationship Inventory (CADRI).${ }^{17}$ developed the Index of Spouse Abuse, which measured both the physical and non-physical aspects and, ${ }^{18}$ behavioral control. It was validated with the Scale of Sexual Assertiveness, and its alpha reliability ranges between 0.60 and 0.81. proposed the Questionnaire of Violence between Couples with 5170 people participants in Spain, Argentina and Mexico. ${ }^{19}$ The questionnaire has eight factors, labeled as types of abuse: emotional punishment, coercion, detachment, physical, gender, humiliation, instrumental and sexual. The model explains $51.3 \%$ of variance and it reported alphas between 0.58 and 0.81 . This questionnaire includes physical, psychological and sexual components of violence. Reported the Out-group Threat Perception Scale's validity and reliability coefficients. ${ }^{20}$ presented the Exposure to Insecurity and Violence Questionnaire for Adolescents, developed in Mexico to measure mild to severe violence. ${ }^{21}$ although the questionnaire has good psychometric properties, no data on the factor structure is provided. Finally, ${ }^{22}$ developed and validated the Exposure to Violence Questionnaire for children and adolescents. It involved 1986 schoolchildren from 16 educational centers in Biscay, Spain. The questionnaire consists of 21 items, 9 regarding direct exposure or victimization and 12 related to indirect exposure. The items refer to three types of violence-physical, verbal and threats-in four contexts: school, neighborhood, home and TV. This instrument was used to asses EVS's concurrent validity since the theme, theoretical framework, population, type of response and sampling methods are similar to the ones used here.

\section{Methods}

\section{Procedure}

Following, ${ }^{23}$ recommended mixed sequential design method for the construction of instruments, we generated a pool of items based on a theoretical review and interviews (first phase). A group of experts 
then evaluated the items and a statistical analysis of these evaluations was performed to assess content validity (second phase). Finally in the third phase, we evaluated the scale's reliability and validity with a representative sample of institutionalized adolescents.

\section{Phase I item generation}

Seven adolescents (five men) between the ages of 16 and 19 $(\mathrm{M}=16.71, \mathrm{SD}=1.07)$ were selected from public $(\mathrm{n}=2)$ and private $(n=5)$ high schools in a mid-size city in Mexico. To be included in the sample, the volunteers had to self-identify as having lived direct or indirect violence or having exercised it. In order to ensure item wording was close to adolescents' perspectives and use of language, we followed, ${ }^{24}$ qualitative technique for generating items and then contrasting them against the theory. Semi-structured interviews were performed to generate an in-depth interview guide. These in-depth interviews were used to generate the initial item pool.

\section{Phase 2 expert judges}

Items were sent to 14 judges, all of them experts in violence or in psychometrics, or preferably in both areas. Nine completed the evaluation, however one sent only qualitative judgments, hence, the validation process was made with eight evaluations. The judges who responded were from different regions in Mexico, and of them was from Spain. Four of them were experts in violence, two in psychometrics, and two in both areas.

\section{Phase 3 reliability and validity}

The sample selection for the instrument's reliability and validity evaluation was obtained in two stages. First, out of the 148 high schools in a mid-size city in Mexico, 25 were selected with a $95 \%$ reliability, a $10 \%$ margin of error, and a $12 \%$ response distribution (calculated from the youth delinquency prevalence in the state of San Luis Potosi, Mexico). During the second stage we worked by clusters (classrooms). Each institution ultimately determined the number of students that were allowed to participate. In small institutions, we asked to have access to the entire student population. In large schools however, we requested access to at least one group per semester. Finally, we included in the sample all of the adolescents being held at the Juvenile Detention Center at the time. A total of 1988 adolescents consented to participate. Following suggestion, an attention filter item was added to the instrument. Those participants who did not follow the items instruction were eliminated from the response pool. Instruments with over $10 \%$ of missing responses were also discarded. The final sample consisted of 1720 participants. The final sample consisted of $869(50.5 \%)$ female and $851(49.5 \%)$ males. Table 1 presents the participants' age range. Fifty percent of the sample was in the first year of high school, $27 \%$ in the second year, and $23 \%$ in their last year. Out of a total of 20, 16 adolescents from the Juvenile Detention Center were retained in the sample (See Table 2). Thirty nine point four percent the sample attended a high school inside a high-level violence area of the city, as identified by the local police, while $41.6 \%$ were studying outside, but close to these areas. Seventeen point nine percent were far away from these areas, $1.2 \%$ of the sample attended a high school in rural areas, and $0.9 \%$ were from the Juvenile Detention Center. The majority of participants lived with both parents (74\%). Sixty two percent reported practicing sports, 39\% reported enjoying artistic activities, and remarkably only $33 \%$ describe being economically deprived, despite the fact that their neighborhoods are characterized by their lack of economic resources.
Table I Age, frequency and percentage of the total number of participants

\begin{tabular}{lll}
\hline Age & Frequency & Valid percentage \\
\hline 15 & 633 & 36.8 \\
16 & 467 & 27.2 \\
17 & 466 & 27.1 \\
18 & 154 & 9 \\
Total & 1720 & 100 \\
\hline
\end{tabular}

Table 2 Academic degree of participants by context

\begin{tabular}{lll}
\hline Half & Frequency & Valid percentage \\
\hline$(\mathrm{CI})$ & 16 & 0.9 \\
$\mathrm{I}$ & 853 & 49.6 \\
2 & 8 & 0.5 \\
3 & 420 & 24.4 \\
4 & 27 & 1.6 \\
5 & 396 & 23 \\
Total & 1720 & 100 \\
\hline
\end{tabular}

\section{Data analysis}

Data analysis was conducted with $\mathrm{R}$ version 3.1.0. ${ }^{25}$ Factor analyses were used to evaluate psychometric performance of the Exposure to Violence Scale. Missing data was imputed using the Multivariate Imputation by Chained Equations. ${ }^{26}$ The sample was randomly split in two. An exploratory factor analysis (EFA) with varimax rotation was used on the first half. The Very Simple Structure, ${ }^{27}$ Minimum Average Partial and Parallel Analysis criteria were used to determine the number of factors to retain..$^{28} \mathrm{~A}$ maximum likelihood confirmatory factor analysis (CFA) was conducted on the second half of the data, using AMOS 21.0 software, to test the factor structure obtained by the EFA. Concurrent validity was evaluated using, ${ }^{29}$ questionnaire on exposure to violence for children and adolescents.

\section{Instruments}

Exposure to violence was assessed with the Exposure to Violence Questionnaire for Children and Adolescents. ${ }^{29}$ This scale was also used to evaluate the EVS's concurrent validity.

\section{Ethical considerations}

Following the American Psychological Association's Ethical Principles of Psychologists and Code of Conduct (sections 8.01, 8.05, and 8.08; APA, 2010) and the Mexican Psychological Society's Ethics Code for Psychologists (articles 122, 124-126, and 136, ${ }^{30}$ we asked each institution to approve the research protocol. Participants were explained the purpose and characteristics of research and chose freely whether or not to participate anonymously.

\section{Results}

\section{Phase I item generation}

From the interviews we obtained three items categories: (a) witnessed or experienced psychological violence, (b) witnessed or experienced physical violence, and (c) sexual violence. A total of 80 items sent to judges for content validation. 


\section{Phase 2 expert judges}

Judges were given a set of criteria and were asked to evaluate each item on a 5 point scale. We retained items with an average score of 4 or above. Those with a score of 3.9 or above, but less than 4.0 were amended and reevaluated by the judges $(\mathrm{k}=13)$. All of them were retained. We discarded any item with s score below 3.9 or an Aiken's V smaller than $0.7(\mathrm{k}=22)$, as suggested. ${ }^{31}$ We obtained an Aiken's $\mathrm{V}$ coefficient of $0.76(95 \% \mathrm{CI}: 0.60$ and 0.895$)$ for the remaining 58 items. Following suggestions, ${ }^{32}$ Kendall's W concordance coefficient was used to assess the agreement between judges. We found a concordance level of 0.493 , which according to to is in the moderate range $(0.41-0.60){ }^{33}$

\section{Phase 3 reliability and validity}

This section describes the steps followed for both EFA and CFA analyses, which yielded the final EVS, show in Figure 3. A random half of the sample ( $\mathrm{n}=793)$ was used to run an exploratory factor analysis (EFA), which yielded a four factor solution with a VSS complexity of 0.8 . Fourteen items with loadings smaller than 0.40 were excluded and another 23 due poor psychometric properties. Considering that the fourth factor had only three items, we proceed to run a three factor EFA. Three more items were eliminated, the first one did not load on $\mathrm{G}$, while the other two had equal loadings on two factors. The final EFA structure is presented in Figure 1 and the factor loadings in Table 3. A CFA, with the 927 remaining participants, yielded a two-factor solution with an eigen value of 5.16, explaining $47 \%$ of the variance. Table 4 shows the different properties for a variety of models that where tested. Table 3 shows the exploratory factor analysis and their factor loadings. The last EFA model shows a total SS loading sum of 10.439 , a proportion of 0.37 , and a cumulative variance of 0.822 . Also a Lower Control Limit of 0.897 alpha of 0.905 and Upper Control Limit of 0.913 . After deciding on a three factor model, we performed a CFA with the 969 participants that had not been considered in the EFA. The CFA was conducted with AMOS 21.0 using maximum likelihood estimates. In order to obtain ideal psychometric properties we eliminated every item with larger loadings in the standardized residual covariances. After we achieve the expected properties we presented a model which can be appreciated in Figure 2, it has two factors and seven items. Also we use a common latent factor for reduce the method bias as it can be appreciated in Figure 3. The standardized regression weights were the same with a common latent factor that without it, we impute to show the results of common method bias. At last in Table 5 it can be appreciated the reliability and validity characteristics of the scale. Once the final model was obtained EVS was correlated to questionnaire to analyze the concurrent validity (shown in Table 6). ${ }^{8}$

Table 3 Exploratory factor analysis (EFA) of the exposure to violence scale

\begin{tabular}{llll}
\hline Item & Factor I & Factor 2 & Factor 3 \\
\hline Exp I14 & 0.637 & - & - \\
$\operatorname{exp~I15~}$ & 0.729 & - & - \\
$\operatorname{exp~I16}$ & 0.747 & - & - \\
$\operatorname{exp~120}$ & 0.53 & - & - \\
$\exp 122$ & 0.695 & - & - \\
$\exp 124$ & 0.639 & - & - \\
\hline
\end{tabular}

Table Continued...

\begin{tabular}{|c|c|c|c|}
\hline Item & Factor I & Factor 2 & Factor 3 \\
\hline $\exp 126$ & 0.66 & - & - \\
\hline $\exp 128$ & 0.55 & - & - \\
\hline $\exp 133$ & 0.509 & - & - \\
\hline $\exp 2$ & - & 0.62 & \\
\hline $\exp 3$ & - & 0.621 & \\
\hline $\exp 4$ & - & 0.649 & \\
\hline $\exp 6$ & - & 0.568 & \\
\hline $\exp 8$ & - & 0.56 & \\
\hline $\exp 10$ & - & 0.569 & \\
\hline $\exp 16$ & - & - & 0.646 \\
\hline $\exp 17$ & - & - & 0.658 \\
\hline $\exp 18$ & - & - & 0.521 \\
\hline $\exp 5$ & - & 0.466 & 0.349 \\
\hline $\exp 15$ & - & - & 0.488 \\
\hline $\exp 20$ & - & - & 0.478 \\
\hline $\exp 21$ & - & 0.309 & 0.488 \\
\hline $\exp 22$ & - & 0.416 & 0.329 \\
\hline $\exp 25$ & - & - & 0.407 \\
\hline $\exp 28$ & - & - & 0.436 \\
\hline $\exp 119$ & 0.416 & - & - \\
\hline $\exp 123$ & 0.477 & - & - \\
\hline $\exp 129$ & 0.447 & - & - \\
\hline $\exp 134$ & 0.482 & - & - \\
\hline
\end{tabular}

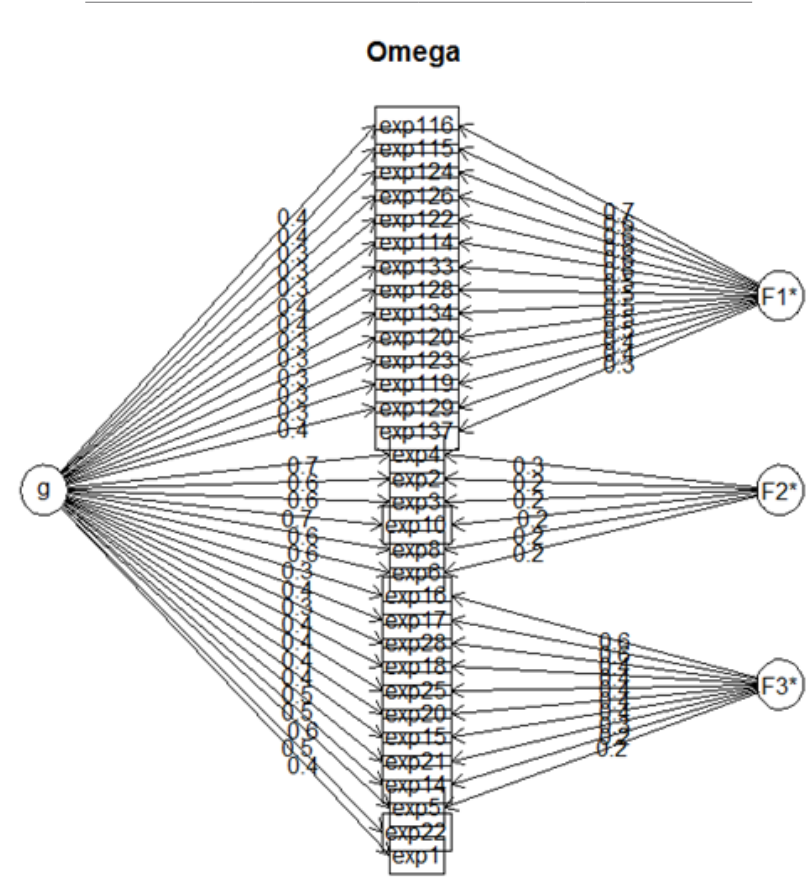

Figure I Omega of the exploratory factor analysis. 
Table 4 Psychometric properties of the exposition to violence scale, initia model, final and common latent factor model

\begin{tabular}{llll}
\hline Index/score & $\begin{array}{l}\text { Initial } \\
\text { model }\end{array}$ & $\begin{array}{l}\text { Final } \\
\text { model }\end{array}$ & $\begin{array}{l}\text { Common latent } \\
\text { factor model }\end{array}$ \\
\hline Cmin/df & 4.6 & 1.424 & 1.553 \\
P-value for the model & 0 & 0.146 & 0.105 \\
CFI & 0.842 & 0.998 & 0.997 \\
GFI & 0.857 & 0.995 & 0.995 \\
AGFI & 0.834 & 0.988 & 0.987 \\
SRMR & 0.0057 & 0.00048 & 0.00048 \\
RMSEA & 0.067 & 0.021 & 0.024 \\
PCLOSE & 0 & 0.992 & 0.983 \\
TLI & 0.828 & 0.996 & 0.994 \\
\hline
\end{tabular}

Table 5 Model fit and psychometric properties

\begin{tabular}{ll}
\hline Measure & Result \\
\hline chi-square & 16.185 \\
P-value for the model & 0.183 \\
CFI & 0.993 \\
GFI & 0.995 \\
AGFI & 0.989 \\
SRMR & 0.0161 \\
RMSEA & 0.019 \\
PCLOSE & 0.995 \\
\hline
\end{tabular}

Table 6 Psychometric properties of the exposure to violence scale

\begin{tabular}{|c|c|c|c|c|c|c|c|c|}
\hline $\begin{array}{l}\text { Reactivo } \\
\text { label }\end{array}$ & reactivo & Factor & $\begin{array}{l}\text { Standardized } \\
\text { regression weights }\end{array}$ & Estimate & SE & CR & AVE & MSV \\
\hline $\exp 122$ & Call me with nicknames that I do not like & Live Violence & 0.62 & I & 0.05 & & & \\
\hline $\exp 120$ & Criticize my way to speak, dress, etc. & Live Violence & 0.63 & 0.92 & 0.05 & & & \\
\hline $\exp 116$ & They made fun of me & Live Violence & 0.81 & 0.48 & 0.03 & & & \\
\hline $\exp I 15$ & They tend to make jokes & Live Violence & 0.79 & 0.46 & 0.03 & 0.88 & 0.52 & 0.3 \\
\hline $\exp 6$ & $\begin{array}{l}\text { I've heard that they criticize others for his } \\
\text { physical, way of dressing, etc. }\end{array}$ & Witness Violence & 0.58 & 0.94 & 0.05 & & & \\
\hline $\exp 4$ & I have heard insults to others & Witness Violence & 0.78 & 0.44 & 0.03 & & & \\
\hline $\exp 2$ & I've seen that they verbally bother someone & Witness Violence & 0.74 & 0.56 & 0.04 & 0.81 & 0.5 & \\
\hline
\end{tabular}

All with a significance of 0.001

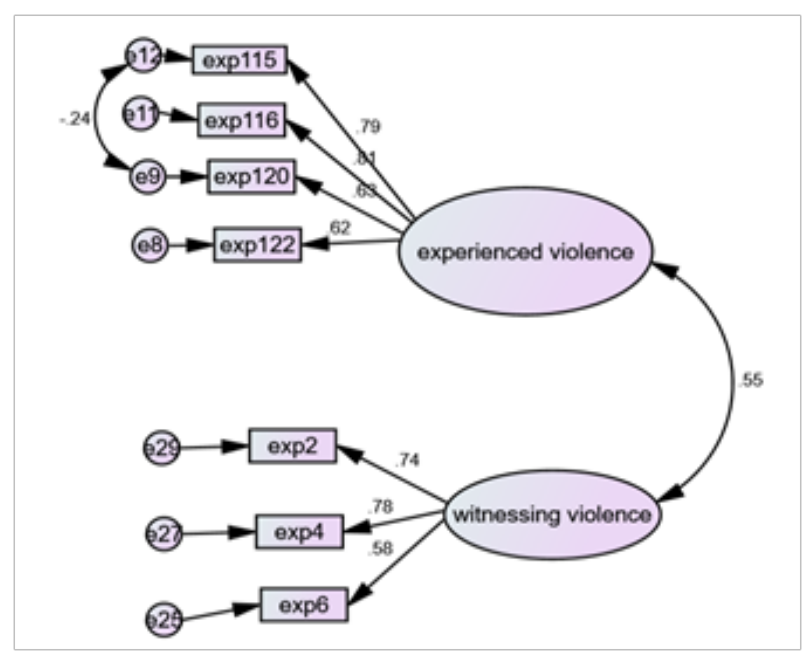

Figure 2 Confirmatory factor analysis of the exposure to violence scale.

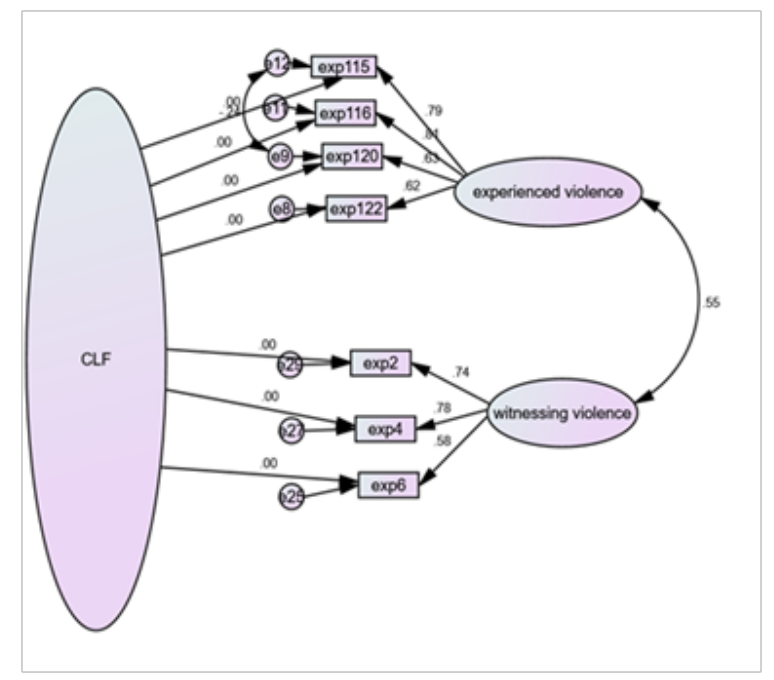

Figure 3 Common latent factor 


\section{Discussion}

The exposure to violence could be experienced as a direct or indirect exposure. The results reveal that the exposure to violence scale has appropriate psychometric properties. It is necessary and pertinent for Mexico to study the consequences beyond the biological consequences of violence (harm, injury, wounds). The effects and sequels of witnessing or living direct violence are fear, anxiety depression, post-traumatic stress disorder, low self-esteem, aggression, higher risk of leaving home, quit school, suicidal attempts, and criminal conduct among others. ${ }^{9}$ At the time it was made the comparison of our instrument with the one of which focuses on couples, we found that it is similar to the scale of exposure to violence, by having a proposal, in the words of the authors, "classical" involving psychological, physical and sexual violence (as the initial proposal of the scale). Also, it allows a good delimitation of whether violence is received direct or indirectly, key factors of the social learning theory Table 7 . With similar limitations, also worked with adolescents but mainly regarding dating situations, excluding a large part of the population which was intended to cover. On the other hand, questionnaire has excellent psychometric properties and concurs with our theoretical approach in almost all its purposes, reasons why it was used to give concurrent validity to our instrument. Finally, the work of has similar features and it is validated for Mexican population, but one of its components is not related to the subject we pretend to approach and it does not. In addition our proposed scale has better GFI, explained variance, SMRS and best sample characteristics (randomness by institutions and size). ${ }^{34-38}$

Table 7 Concurrent validity between the exposure to violence scale and the questionnaire to measure exposure to violence in childhood and adolescence

\begin{tabular}{|c|c|c|c|c|c|c|c|c|}
\hline S. No & $\begin{array}{l}\text { Witness } \\
\text { violence at } \\
\text { the school }\end{array}$ & $\begin{array}{l}\text { Witness } \\
\text { violence on } \\
\text { the street }\end{array}$ & $\begin{array}{l}\text { Witness } \\
\text { violence } \\
\text { at home }\end{array}$ & $\begin{array}{l}\text { Witness } \\
\text { violence } \\
\text { in TV }\end{array}$ & $\begin{array}{l}\text { Live violence } \\
\text { on the school }\end{array}$ & $\begin{array}{l}\text { Live violence } \\
\text { on the street }\end{array}$ & $\begin{array}{l}\text { Live } \\
\text { violence at } \\
\text { home }\end{array}$ & $\begin{array}{l}\text { Total Oruey } \\
\text { Calvete }\end{array}$ \\
\hline Live violence & $0.345^{* *}$ & $0.468^{* *}$ & $0.199 * *$ & $0.213^{* *}$ & $0.255^{* *}$ & $0.337^{* *}$ & $0.163^{* *}$ & $0.45 I^{* *}$ \\
\hline Witness violence & $0.459 * *$ & $0.301 * *$ & $0.219 * *$ & $0.269 * *$ & $0.311 * *$ & $0.205^{* *}$ & $0.204 * *$ & $0.448 * *$ \\
\hline $\begin{array}{l}\text { Total scale of } \\
\text { exposure to } \\
\text { violence }\end{array}$ & $0.465^{* *}$ & $0.456 * *$ & $0.244 * *$ & $0.280 * *$ & $0.328 * *$ & $0.322 * *$ & $0.213^{* *}$ & $0.526 * *$ \\
\hline
\end{tabular}

**The correlation is significant at the level 0.01 (bilateral).

\section{Conclusion}

The possibility of register exposure to violence as a phenomenon that is happening on direct and indirect levels, in both physical and psychological aspects, made the scale a key tool for actual research, since violence is not limited to what is experienced directly, on the contrary, it also adheres to what social learning theory has proved since decades, that there is a vicarious experience, and this represents a symbolic modeling that will affect people that testifies (listen or witnessed) or that lives it directly. Its psychometric properties enable the view of a panorama with great accuracy of the nature of violent events that commonly permeate the life of young people regardless of their context, therefore, generates a broad overview of violence, of who live it direct or indirectly.

The limitations for the scale mainly reside in the sample selection since the sample although wide, it only encompass high school students and institutionalized adolescents as contrast population leaving aside a set of adolescents whom does not belong to this groups and could represent a blur point in the answers.

\section{Acknowledgements}

None.

\section{Conflict of interest}

The authors declared that there is no conflict of Interest.

\section{References}

1. Cooley-Strickland M, Quille TJ, Griffin RS, et al. Effects of youth's exposure to community violence: the more project. Psychosocial Intervention. 2011;20(2):131-148.

2. Cuevas MC, Castro L. Efectos emocionales y conductuales de la exposición a violencia en niños y adolescentes en Colombia. Psychology/ Psicología Conductual. 2009;17(2):277-297.

3. Velicer W. Determining the number of components from the matrix of partial correlations. Psychometrika. 1976;41(3):321-327.

4. Gaylord-Harden NK, Cunningham JA, Zelenik B. Effects of exposure to community violence on internalizing symptoms: does desensitization to violence occur in African American youth? Journal of Abnormal Child Psychology. 2011;39(5):711-719.

5. Houston J. Effects of violence on youths' perceptions of peer and sibling aggression. USA; 2011.

6. Phelps LF, Mccart MR, Davies WH. The impact of community violence on children and parents: development of contextual assessments. Trauma Violence \& Abuse. 2002;3(3):194-209.

7. Santos-Iglesias P, Sierra JC, Vallejo-Medina P. Propiedades psicométricas del index of spouse abuse en una muestra de varones españoles. Terapia psicológica. 2013;31(2):209-217.

8. Su M, Mrug S, Windle M. Social cognitive and emotional mediators link violence exposure and parental nurturance to adolescent aggression. Journal of Clinical Child \& Adolescent Psychology. 2010;39(6):814-824.

9. Van Buuren S, Groothuis-Oudshoorn K. Mice: Multivariate Imputation by Chained Equations in R. Journal of Statistical Software. 2011;45(3):1-67.

10. Villarreal ME, Sánchez JC, Musitu G. Un modelo predictivo de la violencia escolar en adolescentes. Ciencia Uanl. 2010;13(4):413-420.

11. Benítez JL, Muñoz JF. Análisis factorial de las puntuaciones del CADRI en adolescentes universitarios españoles. Universitas Psychologica. 2014;13(1):1-19.

12. Global Peace Index. Denmark; 2013.

13. Funk JB, Baldacci HB, Pasold T, et al. Violence exposure in real life, video games, television, movies, and the Internet: Is there desensitization? Journal of Adolescence. 2004;27(1):23-39. 
14. Ruscio J, Roche B. Determining the number of factors to retain in an exploratory factor analysis using comparison data of known factorial structure. Psychological Assessment. 2012;24(2):282-292.

15. Willis D, Hawkins JW, Pearce CW, et al. Children who witness violence: what service do they need to heal? Issues in Mental Health Nursing. 2010;31(9):552-560.

16. Kelly S. The psychological consequences to adolescents of exposure to gang violence in the community: an integrated review of the literature. Journal of Child and Adolescent Psychiatric Nursing. 2010;23(2):61-73.

17. Galán JS, Preciado. Violence desensitization: delimitating a construct through a theoretical revision. Uaricha. 2014;11(25):70-81.

18. Gómez HL, Gómez-Maqueo EL, Durán C. Confiabilidad y validez de un cuestionario de exposición a la violencia para jóvenes. Acta de investigación psicológica. 2013;3(1):1005-1017.

19. Klopper I. The relationship between exposure to violence and moral development of adolescents. USA; 2010.

20. Cuadrado I, Navas M, López-Rodríguez L. Fiabilidad y evidencias de validez de Escala de Percepción de Amenaza Exogrupal (EPAE). Psicothema. 2012;24(3):477-482.

21. Shukla K, Wiesner M. Relations of delinquency to direct and indirect violence exposure among economically disadvantaged, ethnic-minority mid-adolescents. Crime \& Delinquency. 2013;1-22.

22. Mrug S, Windle M. Prospective effects of violence exposure across multiple contexts on early adolescents' internalizing and externalizing problems. Journal of Child Psychology and Psychiatry. 2010;51(8):953961.

23. Goodearl AW, Salzinger S, Rosario M. The association between violence exposure and aggression and anxiety: the role of peer relationships in adaptation for middle school students. Journal of Early Adolescence. 2014;34(5):311-338.

24. Hernández R, Fernández C, Baptista MP. Metodología de la investigación México: Mc Graw Hill; 2014.

25. Instituto Nacional de Estadística y Geografía. Encuesta Nacional de Victimización y Percepción sobre Seguridad Pública (ENVIPE). 2014.

26. Merino C, Livia J. Intervalos de confianza asimétricos para el índice la validez de contenido: Un programa Visual Basic para la V de Aiken. Anales de psicología. 2009;25(1):169-171.
27. Revelle W, Rocklin T. Very simple structure: an alternative procedure for estimating the optimal number of interpretable factors. Multivariate behavioral research. 1979;14:403-414.

28. Rodríguez-Franco L, López-Cepero J, Rodríguez FJ, et al. Validación del cuestionario de violencia entre novios (CUVINO) en jóvenes hispanohablantes: Análisis de resultados en España, México y Argentina. Anuario de Psicología Clínica y de la Salud. 2010;6:45-52.

29. Orue I, Calvete E. Elaboración y validación de un cuestionario para medir la exposición a la violencia en infancia y adolescencia. International Journal of Psychology and Psychological Therapy. 2010;10(2):279-292.

30. Sociedad Mexicana de Psicología. Código ético del psicólogo. México: Trillas;2007.

31. Escobar-Pérez J, Cuervo-Martínez A. Validez de contenido y juicio de expertos: una aproximación a su utilización. Avances en medición. $2008 ; 65: 27-36$

32. Staude-Müller F, Bliesener T, Luthman S. Hostile and Hardened? An Experimental Study on (De-)Sensitization to Violence and Suffering Through Playing Video Games. Swiss Journal of Psychology. 2008;67(1):41-50.

33. Van Dulmen MHM, Bellinston LM, Flannery DJ, et al. confirmatory factor analysis of the recent exposure to violence scale. Children \& Schools. 2008;30(2):93-102.

34. American Psychological Association. Ethical principles of psychologists and code of conduct. USA; 2017.

35. Bandura A. Aggression a social learning analysis. New Jersey: PrenticeHall; 1977.

36. Bandura A. Social learning theory. Estados Unidos de América: PrenticeHall;1977.

37. Floyd FJ, Widaman KF. Factor analysis in the development and refinement of clinical assessment instruments. Psychological Assessment. 1955;7(3):286-299.

38. Global Peace Index. USA; 2015. 